\title{
BRYOZOA OF KII PENINSULA
}

$\operatorname{AUTHOR}(\mathrm{S})$ :

Mawatari, Shizuo

CITATION:

Mawatari, Shizuo. BRYOZOA OF KII PENINSULA. PUBLICATIONS OF THE SETO MARINE BIOLOGICAL LABORATORY 1952, 2(2): 261-288

ISSUE DATE:

1952-10-05

URL:

http://hdl.handle.net/2433/174675

RIGHT: 


\title{
BRYOZOA OF KII PENINSULA ${ }^{1) 2 ; 3)}$
}

\author{
SHIzUo MAWATARI \\ Research Institute for Natural Resources, Tokyo.
}

With Plate XII and 19 Text-figures

Last summer I had a chance to make a small collection of Bryozoa at Sugashima, Nakiri, Hamajima and Shirahama on the eastern and western coasts of Kii Peninsula. And moreover, during my stay at the Seto Marine Biological Laboratory, Dr. H. UTiNomi and Dr. T. Tokioka very generously placed the valuable collection of these animals in the Laboratory at my disposal and more courteously submitted a kind offer to publish my results.

I have made, on this opportunity, re-examination of many specimens on which my 1938 report is based, together with other materials obtained along the coast of the peninsula. Field notes and unpublished manuscripts are also re examined thoroughly. And I have found 92 genera and 152 species and varieties listed up in the following table, of which 5 species and varieties seem to be new to science.

Table 1. List of species collected at the localities.

(Those with asterisks were described by SAKAKURA (1935) and not seen in materials at hand, and those in roman type are commented upon in detail in the systematic account.

\begin{tabular}{|c|c|c|c|c|c|c|c|c|c|c|}
\hline \multirow[b]{2}{*}{ Name of Species } & \multicolumn{7}{|c|}{ Wakayama Pref. } & \multicolumn{3}{|c|}{ Mie Pref. } \\
\hline & 营 & 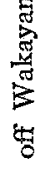 & 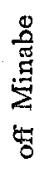 & 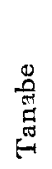 & 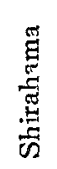 & 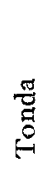 & 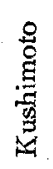 & 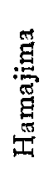 & $\frac{\sqrt{y}}{\pi}$ & 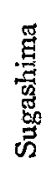 \\
\hline ENTOPROCTA & & & & & & & & & & \\
\hline $\begin{array}{l}\left.\text { Barentsia discreta }{ }^{\prime} \mathrm{BUSK}\right) \\
\text { Pedicellina cernua (PALLAS) } \\
\text { Loxosoma sp. }\end{array}$ & + & & $\begin{array}{l}+ \\
+\end{array}$ & & $\begin{array}{l}+ \\
+ \\
+\end{array}$ & & + & $\begin{array}{l}+ \\
+\end{array}$ & & + \\
\hline
\end{tabular}

1) Contributions from the Seto Marine Biological Laboratory, No. 186.

2) Contributions from the Research Institute for Natural Resources, No. 547.

3) Studies on the Bryozoan Fauna of Japan and Adjacent Waters. No. 1.

Publ. Seto Mar. Biol. Lab., II (2), 1952. (Article 16) 


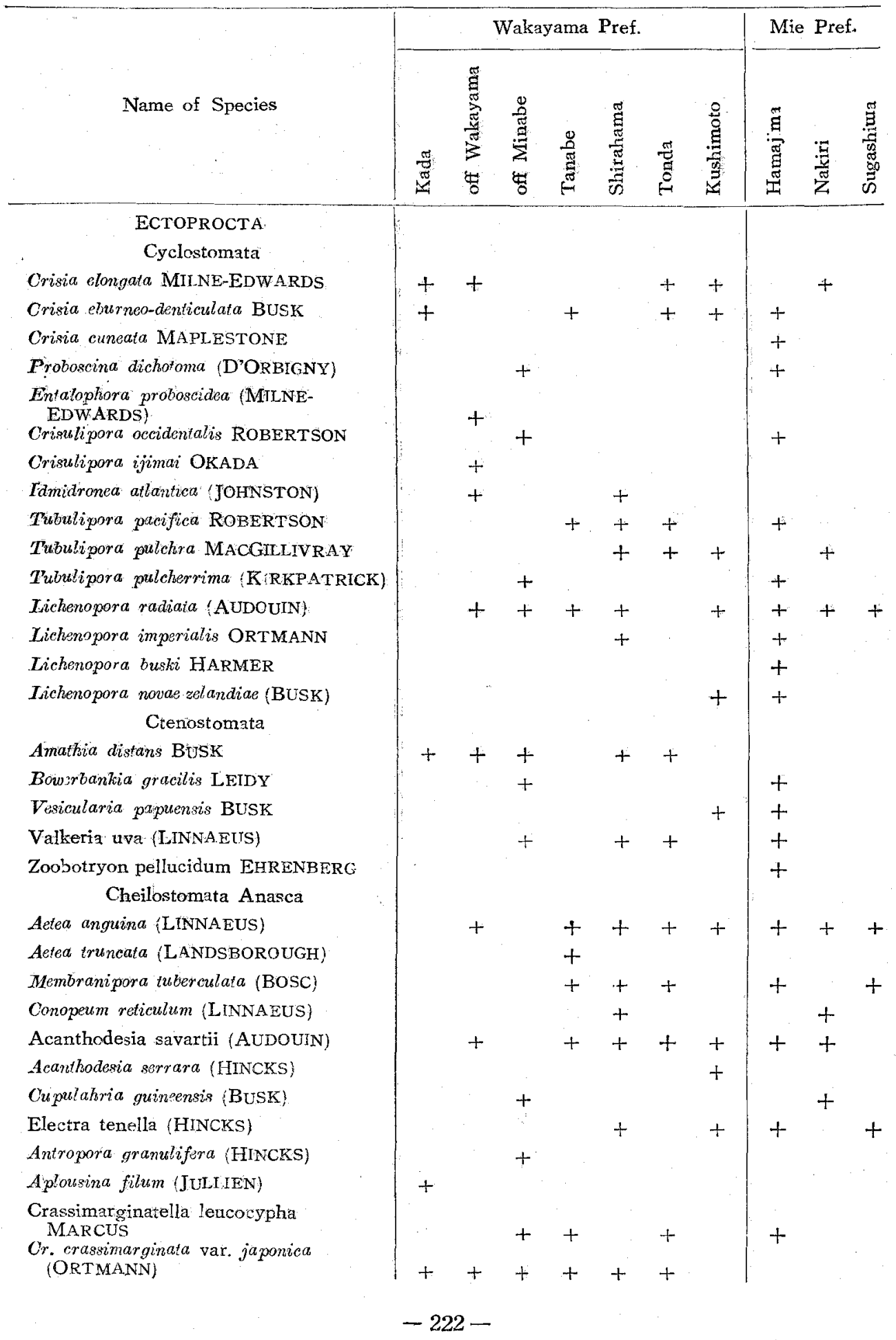




\begin{tabular}{|c|c|c|c|c|c|c|c|c|c|c|}
\hline \multirow{2}{*}{ Name of Species } & \multicolumn{7}{|c|}{ Wakayama Pref. } & \multicolumn{3}{|c|}{ Mie Pref. } \\
\hline & 离 & 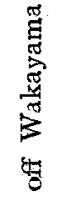 & 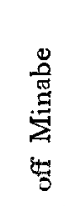 & 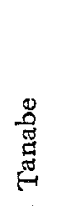 & 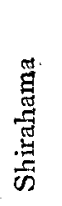 & 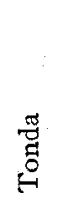 & 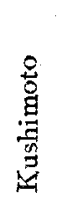 & 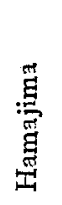 & 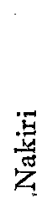 & 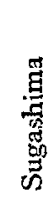 \\
\hline Tegella eremulata (OKADA) & + & + & + & + & + & + & & + & & \\
\hline Tegella incrustata SIL $\mathrm{QN}$ & & & & & & & + & & & \\
\hline Callopora tenuirostris WATERS & & & & & + & & & + & & \\
\hline Callopora canui S LEN & & & + & & + & & + & + & & \\
\hline Ellisina albida (HINCKS) & & & & + & & & & & & \\
\hline Ellisina canui (SAKAKURA) & & + & + & & + & + & & & + & \\
\hline Parellisina curvirostris (HINCKS) & & & & & + & & + & & & \\
\hline Copidozoum planum (HINCKS) & & & + & & & & & & & \\
\hline Hiantopora intermedia (KIRKPATRICK) & & + & & & & & & & & \\
\hline Pyrulella corbula (HNCKS) & & & & & & & & + & & \\
\hline Exechonella magna (MACGILLIVRAY). & & & & & + & & & + & & \\
\hline Flustra stolonifera (OKADA) & & & & + & & & & & & \\
\hline Flustra papyracea ELLIS and SOLANDER & & & + & & & & & & & \\
\hline Terminoflutstra sagamiensis (OKADA) & & & & + & & & & & & \\
\hline Spiralaria serrata (MACGILIIVRAY) & & & & & + & & + & + & & \\
\hline Steganoporella magnilabris (BUSK) & & + & + & & & & & & & \\
\hline *Iabioporella elegans (SAKAKURA) & loff & Kii & Penin & ula) & & & & & & \\
\hline Labioporella rhomboidalis sp. n. & & & & + & + & & & + & & \\
\hline Thalamoporella rozieri (AUDOU $\mathrm{N}$ ) & & + & + & & & & & & & \\
\hline Thalamoporella lioticha (ORTMANN\}) & & + & + & & & & & & & \\
\hline *Rosseliana sibatai SAKAKURA & loff & Kii & Penir & sula) & & & & & & \\
\hline Micropora coriacea ESPER & & & + & & + & & & + & & \\
\hline Monoporella nodulifera (HINCKS) & & & & + & & & & & & \\
\hline Cellaria punctata (BUSK) & + & + & & + & & & & & & \\
\hline Tricellaria oceidentalis (TRASK) & & + & + & & + & & & + & & + \\
\hline Amastigia rudis (BUSK) & & & & & + & & & + & & \\
\hline $\begin{array}{l}\text { Notoplites aviculariae (YANAGI and } \\
\text { OKADA) } \\
\text { Caberea darwinii BUSK }\end{array}$ & & + & + & & & & + & & & \\
\hline Caberea hataii OKADA & & & + & & & & & & & \\
\hline Caberea lata BUSK & + & & + & & + & + & + & & & \\
\hline Caberea boryi (AUDOUIN) & & + & & & & & & & & \\
\hline Scrupocellaria delilii (AUDOUIN) & & + & & & & & & & & \\
\hline Ser. diadema BUSK & + & + & + & & & + & & & & \\
\hline Scr. maderensis BusK & + & + & + & & & & & & & \\
\hline Scr. californisa TRASK & + & & & & + & + & & + & & \\
\hline Canda retiformis POURTALES & & & & & & & + & & & \\
\hline Flabellaris patclliormis (BUSK) & + & + & & & ' & & & & & \\
\hline
\end{tabular}




\begin{tabular}{|c|c|c|c|c|c|c|c|c|c|c|}
\hline \multirow[b]{2}{*}{ Name of Species } & \multicolumn{7}{|c|}{ Wakayama Pref. } & \multicolumn{3}{|c|}{ Mie Pref. } \\
\hline & $\underset{\pi}{\pi}$ & 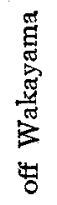 & 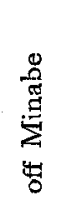 & 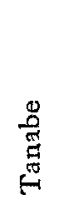 & 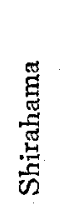 & 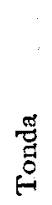 & 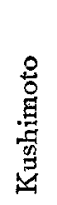 & 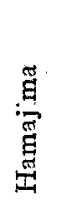 & $\frac{\pi}{\frac{\pi}{4}}$ & 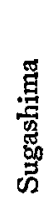 \\
\hline Synnotum aegyptiarum (AUDOUIN) & & & & & & & + & & & \\
\hline Reania magellaniea (BUSK) & & & + & & & & & & & \\
\hline Beania hexaceras (ORTMANN) & + & + & & & & & & & & \\
\hline Beania octaceras OKADA and MAWATARI & + & & & & & & & & & \\
\hline Beania cupulariensis OSBURN & & & & + & + & & & & & \\
\hline Beania discodermiae (ORTMANN) & & & & & + & + & & + & & + \\
\hline Beania mirabilis JOHNSTON & & & & + & + & & + & + & + & \\
\hline Beania regularis THORNELY. & & & & & + & & & + & & \\
\hline $\begin{array}{l}\text { Beania intermedia var. kiiens:s } \\
\text { n. var. } \\
\text { Dendrobeania birostrata (YANAGI and } \\
\text { OKADA) } \\
\text { Bugula dentata (LAMOUROUX) }\end{array}$ & & & + & + & $\begin{array}{l}+ \\
+\end{array}$ & & + & & & \\
\hline Bugula vectifera HARMER & + & + & & & & & & & & \\
\hline Bugula subglobosa HARMER & & & + & & + & & & + & & + \\
\hline Bugula neritina (LINNAEUS) & & + & & + & + & & & & & \\
\hline Bugula sp. & + & + & & + & + & & & + & & \\
\hline Bugula califormica ROBERTSON & & + & & & & & & & & \\
\hline $\begin{array}{l}\text { Bugula pugeti var. umbelliformis YANAGI } \\
\text { and OKADA } \\
\text { Caulibugula ciliata ROBERTSON }\end{array}$ & & + & & & & & + & & & \\
\hline Halophila johnstoniae GRAY & & & + & & & & & & & \\
\hline $\begin{array}{l}\text { Colletosia radiala (MOLL) } \\
\text { Cheilostoma Ascophora }\end{array}$ & & & & & + & & & + & & + \\
\hline Hippothoa hyalina (LINNAEUS) & + & & & & + & + & + & + & + & + \\
\hline Trypostega vemusta (NTORMAN) & & & & & + & & & & & \\
\hline Hippothoa divaricata LAMOUROUX & & & + & & & & & + & & \\
\hline Chorizopora brongniartii (AUDOUIN) & & & & & + & & + & + & & \\
\hline Petralia japonica (BUSK) & + & + & + & & + & & & & & . \\
\hline $\begin{array}{l}\text { Petraliella armata var. mucroaviculata } \\
\text { OKADA and MAWATARI } \\
\text { Galeopsis pupa JULLIEN }\end{array}$ & & + & + & & & & + & & & \\
\hline Selbizoporella unicornis (JOHNST ON) & & & & + & + & + & + & & & \\
\hline Sch. horsti (OSBURN) & & & & & + & & & & & + \\
\hline Sch. nivea BUSK & & & & & + & & + & + & & \\
\hline Sch. kiiensis OKADA \& MAWATARI & & & + & & + & & + & & & \\
\hline Schizomavella auriculata (HASSAL) & & & + & & & & + & & & \\
\hline Sch. galeata (BUSK) & & + & & & & & & & & \\
\hline Arthropoma ceeilii (AUDOUIN) & & & + & + & + & + & + & + & & \\
\hline Microporella ciliata (PALLAS) & & + & & + & + & & + & + & & \\
\hline
\end{tabular}




\begin{tabular}{|c|c|c|c|c|c|c|c|c|c|c|}
\hline \multirow[b]{2}{*}{ Name of Species } & \multicolumn{7}{|c|}{ Wakayama Pref. } & \multicolumn{3}{|c|}{ Mie Pref. } \\
\hline & 莺 & 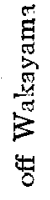 & 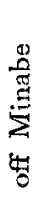 & 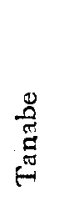 & 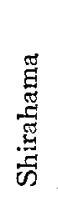 & 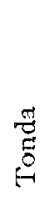 & 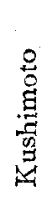 & 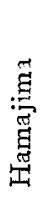 & 总 & 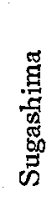 \\
\hline Fenestrulina malusii (AUDOUIN) & & & & & + & + & + & + & + & + \\
\hline Hippodiplosia purtusa (ESPER) & & & & & & & + & & & \\
\hline Hippodiplosia pallaiana (MOLL) & & & + & & & & & & & \\
\hline Hippoporina porcellana (BUSK) & & + & & & & & & & & \\
\hline Eurystcmella bilabiata (HINCKS) & & & & & & + & & + & + & \\
\hline $\begin{array}{l}\text { Exochella areolata OKADA and MAWA- } \\
\text { TARI } \\
\text { Exochella longiroziris JULL EN }\end{array}$ & + & & & & + & + & + & & & + \\
\hline Codonella acuta (ORTMANN) & + & & & & + & & + & & & \\
\hline Cod spatula a OKADA and MAWATARI & & & & & + & + & & & & \\
\hline Codonella ob us ta (ORTMANN) & & + & & & & & & & & \\
\hline Smittina trispinosa (JOHNSTON) & + & & & & + & & & & & \\
\hline Sm. trispinosa nitida (VERRIJ) & & + & & + & + & & & + & & \\
\hline Sm. trispinosa munita (HiNCKS) & & & + & & + & & & + & & \\
\hline Sm. aviculata n. sp. & & & & & + & & & & & \\
\hline Sm, triangularis n. sp. & & & & & + & & & & & \\
\hline$S m$. reticulata (MACGILIVRAY) & & & & & & & + & & & \\
\hline Sm. collifera (ROBFRTSON) & + & & & & + & + & & + & . & + \\
\hline Sm. marmorea (HINCKS) & & & & & & & + & & & \\
\hline$S m$. perforata OKADA & & & & & & & + & & & \\
\hline$S m$. bella (BUSK) & + & + & & + & + & & + & + & + & + \\
\hline Escharoides sauloglossa LEVINSEN & & & + & & & & + & & & \\
\hline Mucronella perforata OKADA & & + & & & & & & & & \\
\hline Mucronella takatsukii OKADA & & + & & & & & & + & & \\
\hline $\begin{array}{l}\text { Tubucellaria cerecides ELLS and } \\
\text { SOLANDER }\end{array}$ & + & + & + & & & & & & & \\
\hline Iodictyum axillare (ORTMANN) & & & & & & + & & & & \\
\hline Iodictyum watanabei (OKADA) & + & & & & & & & & & \\
\hline Sertella granula'a HARMER & & & & & & + & & & & \\
\hline Reteporella graeffei KIRCHENPAUER & & & + & & & & & & & \\
\hline Poteporellina denticulata (BUSK) & & + & & & + & & & & & \\
\hline Triphyllozoon bimunitum (O TMANN) & & + & & & & & & & & \\
\hline Triphyllozoon umbonafum (BUCHNER) & & & + & & & & & & & \\
\hline Adeona japonica (ORThNN\}) & + & + & + & & + & & & & & \\
\hline Adeonellopsis hexangularis OKADA) & & + & + & & & & & & & \\
\hline Mastigophora pes-anceris (S⿵TT) & & & & & & & + & + & & \\
\hline Hippopodina feegonsis $(\mathrm{B} \cup \mathrm{S}$ 列 & & & + & + & & & & & & \\
\hline Watersipora cucullata watersi MA.WATARI & + & & & + & + & + & + & + & + & + \\
\hline
\end{tabular}




\begin{tabular}{|c|c|c|c|c|c|c|c|c|c|c|}
\hline \multirow[b]{2}{*}{ Name of Species } & \multicolumn{7}{|c|}{ Wakayama Pref. } & \multicolumn{3}{|c|}{ Mie Pref. } \\
\hline & 䔍 & 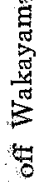 & 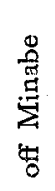 & 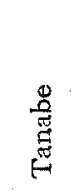 & 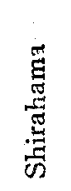 & $\stackrel{\text { ğ }}{\stackrel{0}{0}}$ & 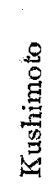 & 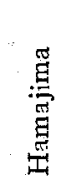 & $\frac{\frac{\vec{G}}{\underline{G}}}{\frac{\pi}{Z}}$ & 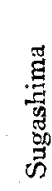 \\
\hline Costazia radiata ORTMANN & & + & & & & + & + & + & + & + \\
\hline Costazia cosiazii (AUDOUN) & & & + & + & + & + & + & + & + & + \\
\hline $\begin{array}{l}\text { Cellepora trirostrata OKADA and MAWA- } \\
\text { TARI }\end{array}$ & & & & & + & & & & & \\
\hline Holoporella tridenticulata (BUSK) & & & & & & & + & & & \\
\hline $\begin{array}{l}\text { Flabellopora transversa CANU and } \\
\text { BASSLER }\end{array}$ & & & $\mathrm{Kii}$ & Peni & asula) & & & & & \\
\hline Vittaticella elegans (BUSK) & + & + & & & & & & & & \\
\hline Haiysisis ijimai (OKADA) & & & $t$ & & + & & & + & & \\
\hline Myriozoum superficiale ORTMANN & + & + & + & & & & & & & \\
\hline Myriozoum serratum n. sp. & & + & + & & & & & & & \\
\hline Entoprocta & & & nera & & & & & & $\begin{array}{l}\text { ies a } \\
\text { rietie } \\
3\end{array}$ & \\
\hline Cyclostomata & & & & & & & & & 15 & \\
\hline Ctenostomata & & & & & & & & & 5 & \\
\hline Cheilostomata Anasca & & & & & & & & & 69 & \\
\hline Cheilostomata Ascophora & & & & & & & & & 60 & \\
\hline Total & & & & & & & & & 152 & \\
\hline
\end{tabular}

It is my pleasant duty to present here my results of study and to tender my best thanks to Drs. UTINomi and Tokioka for their special kindness.

\section{Loxosoma sp.}

A single individual attached to a Sargassum leaf was obtained. The foot is a sucking disc without any wing-like expansions, and provided with faint oblique muscles. No foot-gland is observed. These characters indicate the present specimen belongs to the genus Loxosoma, but the individual is very young to determine the exact specific name.

\section{Valkeria awo (LINNAEUS}

(Fig. 1)

Sertularia uva LiNNAEUS, 1758 , p. 812.

Valkeria uva HINCKS, 1880, p. 551; LEVINSEN, 1894, p. 83; KIRKPATRICK, 1890, p. 17; 
CALVET, 1902, p. 93; BIDENKAP, 1905, p. 44; WATERS, 1910, p. 250; WATERS, 1914, p. 853.

Zoarium repent, delicate, attaching Bugula, Tricellaria, Scrufocellaria and other cellularine Bryozoa with its narrow stolon. The stolon is divided at intervals into many internodes by diaphragms. The distal end of an internode dilates into a little swelling, producing, on each side a branch composed of
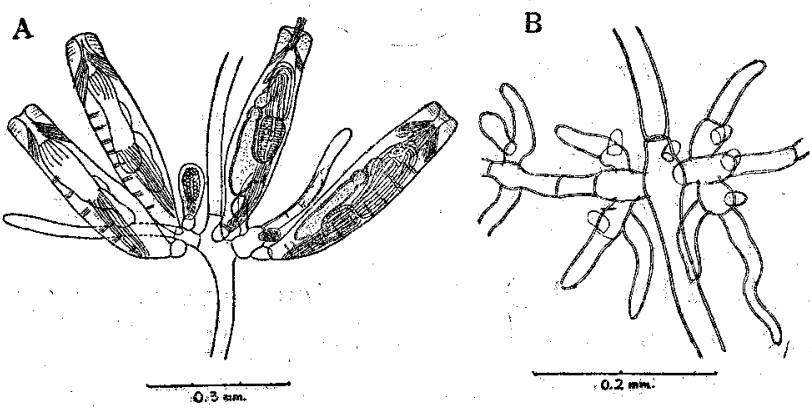

Fig. 1. Valkzria wva (Linnaeus) A Several functional zooecia. B A Stolen showing the mode of branching.

short internodes. The short lateral internode gives off again paired lateral branches. Zooecia arising from a vestigial internode, not crowded into a circular group, subcylindrical, more or less attenuated at the base. Orifice terminal, subquadrangular. Vestibule short, pharyx large, and gizzard not observed.

WATERs reported this species from Sudan attaching to Petralia japonica which is common in Japanese water, The number of zooecia in a group is rather small (4-7) in Japanese specimens.

\section{Zoobolryon pellucidum EHRENBERG}

A small colony attaching to a raft for the pearl oyster culture is obtained at Hamajima. The name of the present species is found in Miss. RoBErTson's unpublished list of Japanese Bryozoa based on Dr. Asajiro Ors's collection at Tateyama, Chiba Prefecture.

I have another complete specimen of this species collected on the bottom of a boat at Misaki, Kanagawa Prefecture which was kindly sent to me by Dr. Katsuma DAN in 1942.

\section{Acanthodesia savartii . (AUDOUIN)}

Opesia at first oval, occupying most of the frontal surface; later invaded. 
by a thickened and somewhat tuberculated crytocyst in its proximal half. The proximal denticle is variable, sometimes may be merely linear and simple, but more often broad and terminated by fine teeth.

\section{Electra tenella (HINCKS)}

(Fig. 2)

Membranipora tenella HiNCKS, 1880, p. 376.

Electa angulata LEVINSEN, 1909, p. 149, 156, 160 ; HARMER, 1916, p. 207; OKADA and MAWATARI, 1938, p. 449 ; SAKAKURA, 1938, p. 717.

Electra tenella MARcus, 1937, p. 48-1938, p. 67 ; OSBURN, 1940, p. 356; SILEN, 1941, p. 18; OSBURN, 1947, p. 10.

Zoarium thin, delicate, brownish in colour, encrusting algae, shells, barnacles, buoys and other floating objects. Zooecia oblong, separated by shallow grooves. Opesium elliptical with a slight proximal cryptocyst. Marginal spines delicate, jointed, varying in number. Operculm with chitinized margin. A pair of strong conical spines or one only, situating on a proximal gymnocyst.

A.

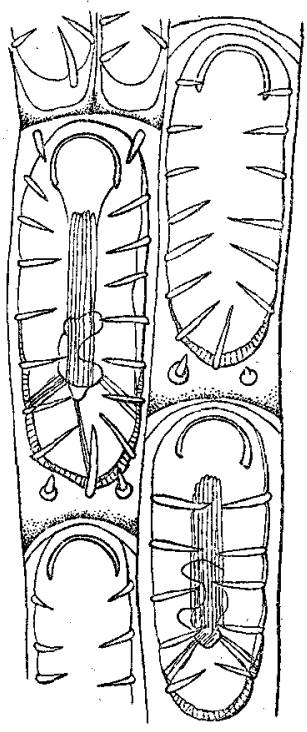

$B$

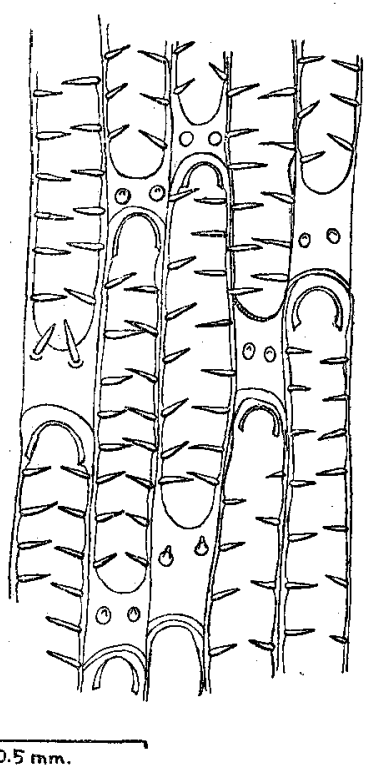

Fig. 2. Electra tenella (Hincks) A normal type of zooecia with narrow proximal cryptocyst. B Unusual. elongate form. 
Avicularia and coecia none.

Hinks figured Membranipora tenella as with no marginal spines, and LeVINSEN figured his Electra angulata as with six to twelve pairs of them. But in its description, HiNcks mentioned that his $M$. tenella is sometimes provided with spines, and Levinsen stated that his E. angulata is of ten unarmoured. The two species described as different agree almost completely with each other in all other respects. SILEN wisely treated them as identical.

\section{Crassimarginatella leücocypha MARCUS}

(Fig. 3)

Crassimarginatella leucocypha MARCUS 1937, p. 46.

Zoarium encrusting shells. Zoocia distinct, oval, with salient margin separated by intercalated kenozoeecia. Gymnocyst not developed, cryptocyst

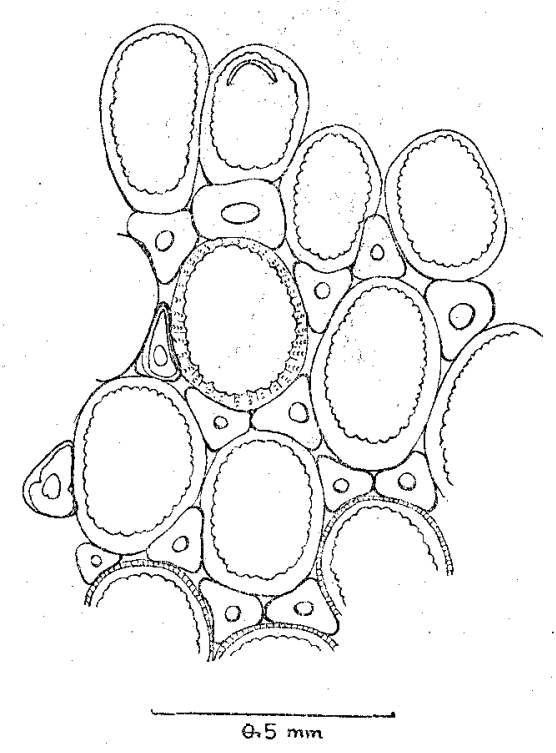

Fig. 3. Orassinarginatella leucocypha Marcus

granular with serrated inner margin. Opesia oval, occupying the greater part of the frontal. Kenozooecia of rounded triangle, provided with a median opening, situating on both sides of the distal end of the zooecia. Avicularia vicarious, occupying the position of one of the kenozocecia.

Material at hand is dead without mandibles. 


\section{Callopora canisi SILEN}

(Fig. 4)

Callopora canui SILEN, 1941, p. 34.

Caltopora horrida CANU and BASSLER, 1929; p. 103 :

Several zoaria attached to stones and shells are collected. Characteristic narrow transverse fenestra is clear on the tuberculated ooecia. The shape and

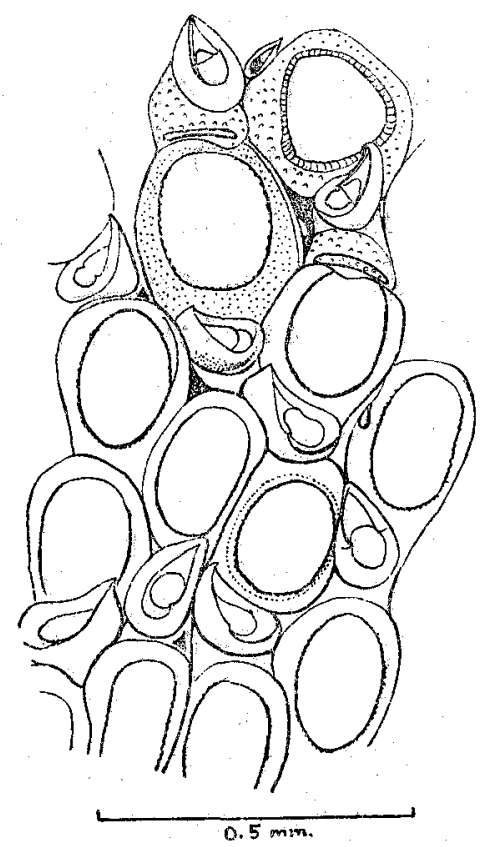

Fig. 4. Callopora canui Silén

postion of avicularium agree with the description and figure of SiLEN. A spine is observed by SiLÉN on each distal corner of the zooecia, but it is not detected in the present material.

\section{Ellisina canui SAKAKURA}

(Fig. 5)

Membrantpora sp. BUCHNER, 1918, p. 459.

Amphiblestrum canui SAKAKURA, 1935. p. 6

Elligina canui SILEN, 1938 , p. $273 ; 1941$; p. 37. 

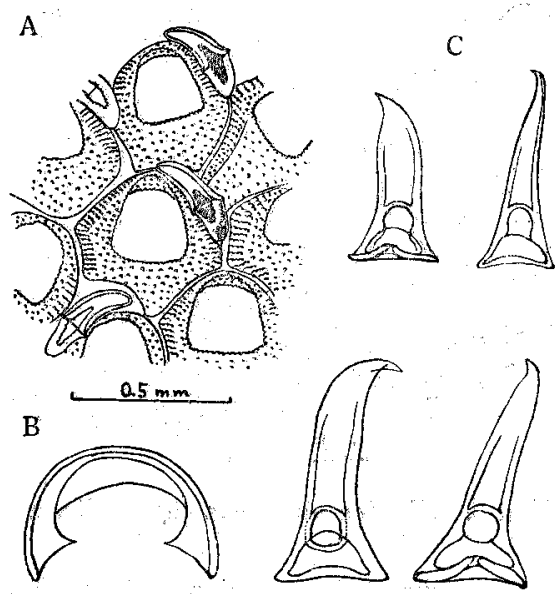

$0.2 \mathrm{~mm}$

Fig. 5. Ellisina canui (Sakakura)
A Zooecia
B. Operculum
C Mandibles

The materials at hand agree with the description and figures of SAKAKURA. SEÉn transfered this species to Ellisina on the presence of the vicarionis avicularia.

\section{Parellisina curvirostris (HINCKS)}

Membranipora curvirostris HINCKS, 1880, p. 153; WATERS, 1898, p. 684; ROBERTSON, 1921, p. 46 .

Callopora curvirastris CANU and BASSLFR, 1825, p. 14; 1927, p. $3 ; 1928$, p. 32.

Ellisina eurvirostris HARMER, 1926, p. 228; HASTINGS, 1930, p. 711; SAKAKURA, 1935, p.

7.

Parellisina curvirostris OSBURN, 1940, p. $361 ; 1949$, p. 4.

\section{Exechonella magna (MACGILLIVRAY)}

(Fig. 6)

Hiantopora magna MACGILLIVRAY, 1895, p. 62.

Exechonella magna CANU and BASSLER, 1929, p. 121.

Zoarium encrusting shells and stones. Zooecia large, oval or elliptical, separated by a furrow. Frontal wall much convex, thick and perforated by ten to thirty pores with salient disc-like rims characteristic of the genus. The 


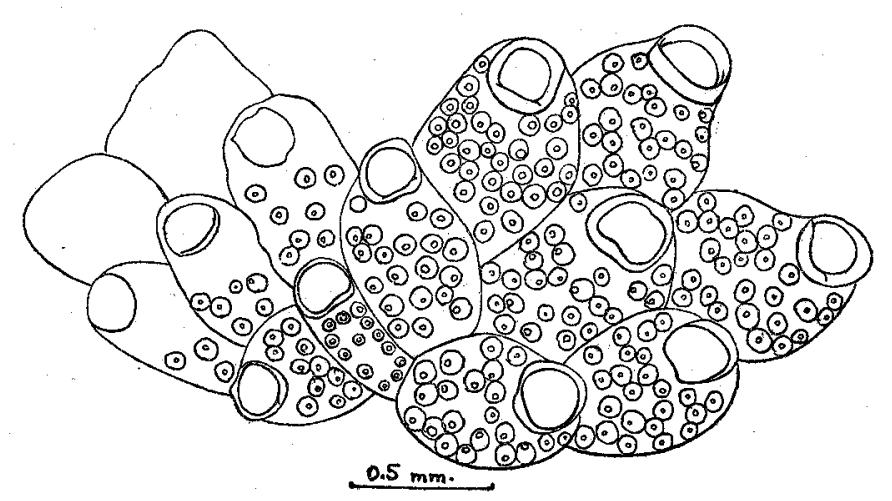

Fig. 6. Fxechonella magna (MacGillivray)

structure of the frontal is quite different from that of the usual tremocyst, the true ectocyst being hidden under calcareous layer of the frontal covering. Orifice large, nearly circular or semi-elliptical with convexed proximal margin. Peristome salient and thick. Ancestrula is of the same structure with the normal autozooecium.

The material at hand is a small colony with only 14 zooecia, differing from the Philipine materials in its larger number of pores and also in the absence of avicularia, probably according to its younger condition.

\section{Spiralaria serrata (MACGILLIVRAY)}

(Fig. 7)

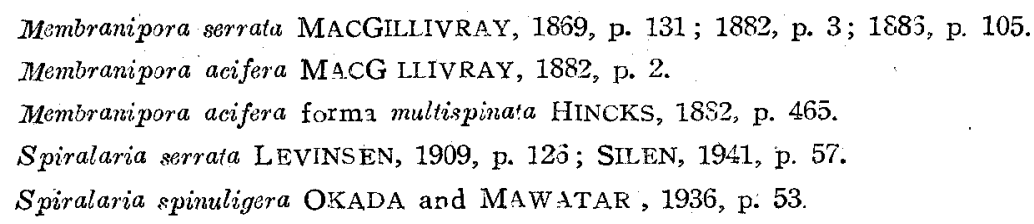

Zoarium encrusting, forming a thin rounded patch of brownish colour on shells. Zooecia elliptical, with large opesia of the same form. Marginal spines pointed, six to eight pairs, extending over the opesia.

Avicularia conspicuous; provided with long curved rostrum extending obliquely distally along a lateral border of the opesia of the succeeding zooecia.

The material at hand agrees well with Hinzs' figure. SiLEN mentioned that Membranipora acifera is identical with $M$. serrata. If it be true, the present material is to be identified to Spiralaria serrata though it differs from SiLess's figure in the character of the marginal spines. 


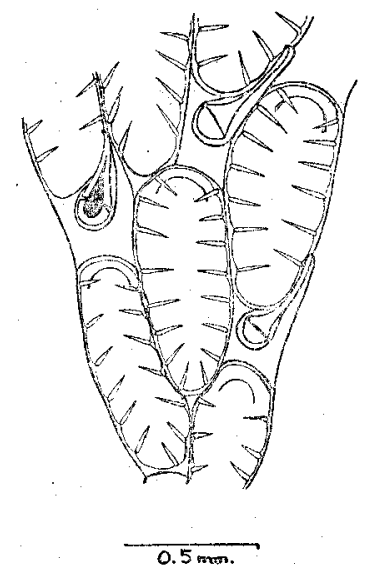

Fig. 7. Spiralaria serrata (MacGillivray)

Labioporella rhomboidalis sp. nov.

(Fig. 8)

Zoarium encusting stones. Zooecia elliptical or oblong, with raised edges. Gymnocyst wanting. Frontal membrane transparent, iridescent, separated by

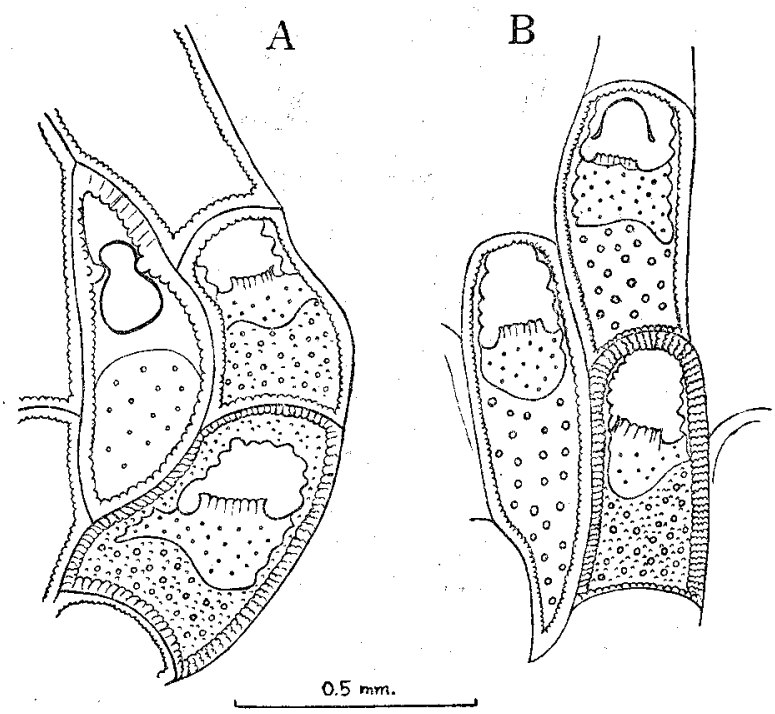

Fig. 8. Labioporella rhomboidalis sp. nov.

A Aviculorium and its neighbouring Zooecium.

B Normal zobecia. 
a brownish line. Tube often asymmetrical, lateral recesses distinct. Horizontal cryptocyst developed, porous, granular, occupying about a half of the frontal surface, with a somewhat wide postoral shelf, extending beyond the lateral sides of the orifice, completely round its distal border. Lateral and distal horizontal cryptocyst strongly crenulated in the region of opesia. Postoral shelf smooth, minutely punctate.

Avicularia large, rhomboidal, the proximal portion usually longer than the triangular pointed rostrum.

Avicularian opesia small, pear-shaped extending beyond the lateral condyles, the distal edge smooth, rounded. Rostral floor small, triangular.

The present new species is quite distinct among the known species of the genus in its rhomboidal avicularia.

SAKAKURA described a new species Labioporella elegans from Kii Peninsula. No avicularia found in his species, and avicularia rare in my material.

\section{Micropora coriacea (JOHNSTON)}

(Fig. 9)

A

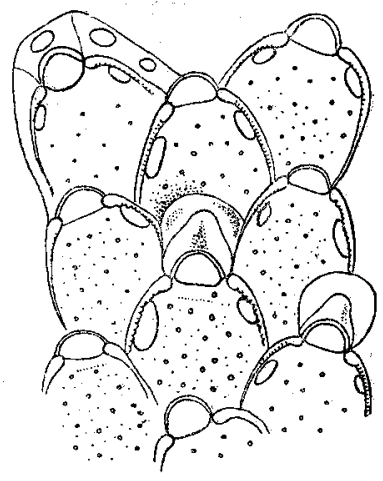

$\mathrm{B}$

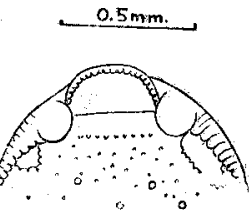

$0.5 \mathrm{~mm}$

Fig. 9. Mieropora coriacea (Johnston)

A Zooecia and ooecia

B Orifice and opesiules 
Fiustra coriacea JOHNSTON, 1847, p. 349 .

Membranipora coriaça BUSK, 1854, p. 57.

Micropora coriacea GRAY, 1848, p. 115; SMITT, 1872, p. 13; HiNCKS, 1880, p. 147, BUKS: 1884, p. 71; KIRKPATRICK, 1788, p. 75; MACG LLIVRAY, 1887, p. 209; WATERS, 1889 ; p. 16; WATFRs, 1904, p. 39; ROBERTSON, 1908, p, 275; NORMAN, 1809, p. 293; CANU and BASSLER, 1920, p. 235; MARCUS, 1921, p. 101 ; CIPOILA, 1921, p. 49; WATERS, 1925, p. 339 ; 1927, p. 8; ODONOGHUE 1926; p. 49; HARMER, 1926, p. 307; CANU and BASSLER, 1935 , p. 138 ; OSBURN, 1840 , p. 373 ; OSBURN, 1947, p. 17 ; MARCUS, 1949, p. 16; OSBURN, 1950, p. 105.

A colony agreeing to the present species is collected off Minabe, encrusting shells. The distal half of the lateral projecting edge finely crenated. A somewhat large conspicuous tubercle on either side of the proximal margin of orifice. Opesiules distinct, asymmetrical with granular edge. Ooecia globose with broad median carina. Operculum very simple, light-coloured.

\section{Cellaria punciaia (BUSK)}

(Fig. 10; Pl. XII, Fig. 6)

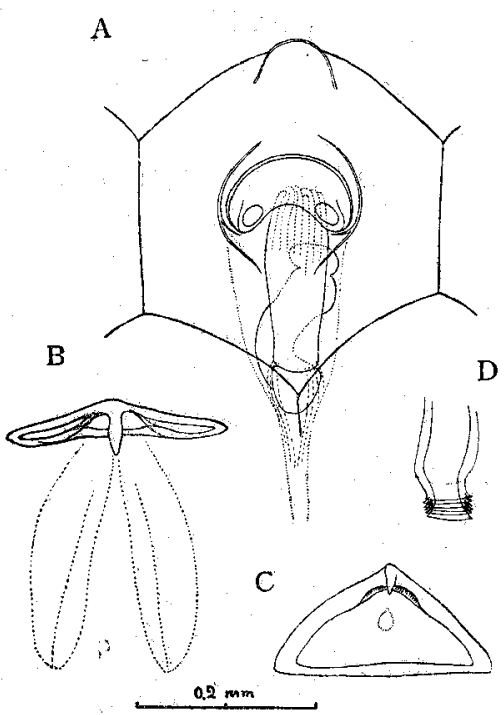

Fig. 10. Oellaria punctata (Busk)

A Decalcified matured zooecium with onecial valve, operculum, depressor sclerite and Polypide.

B Mandible with bund'es of muscles

C Mandible

D Fnd of the connecting tabe 
Salicornaria punctata (pars) Busk, 1852, p. 366.

Salicornaria graeilis BUSK, 1852, p. $17 ; 1884$, p. 93.

Cellaria gracilis WATERS, 1887, p. 92; MARCUS, 1922, p. 19.

Cellaria punctata HARMER, 1926, p. 387; HASTINGs, 1832, p. 413; MARCUS, 1938, p. 206; SILEN, 1941, p. 70.

Cellaria triangularis ORTMANN, 1890 , p. 32; OKADA, 1921, p. 30; 1925, p. 225; 1934, p. 11; SAKAKURA, 1935, p. 15; 1935, p. 108; OKADA and MAWATARI, 1935, p. 132; 1938, p. 350.

Cellaria japonica CANU and BASSLER, 1929, p. 171.

ORTMANN, in his original description, mentioned that his C. triangularis is closely related to $C$. gracilis Busk (synonymous with C. punctata) but differs from it "durch vehältnismassig breitere Felder, durch undeutlich innere Leisten, durch glatten Deckel und durch längere und stärkere Internodien". These differences are insignificant, and re-examination of Japanese materials named C. triangularis resulted that they are all identical with C.puntata.

\section{Scrupocellaria maderensis Busk}

(Fig. 11)

Scrupocellaria maderensis BuSK, 1860, p. $280 ; 1861$ p. 77 ; HARMaR, 1926, p. 372 ; HASTINGS, 1932, p. 410; SILEN 1941, p. 89 .

Scrupocellaria macandrei OKADA and MAWATARI, 1938, p. 452.

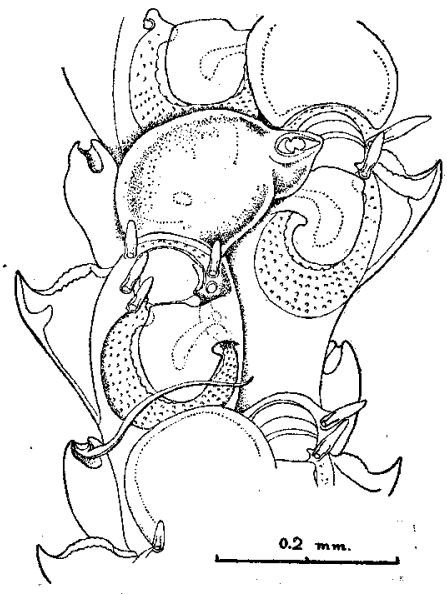

Fig. 11. Scrupocellaria madorensis Busk

The present material with strongly granulated cryptocyst is true Scr macandrei Busk, and it is synonymous with Scr. maderensis Busk. 
Beania intermedia var. kïiensis n. var.

(Fig. 12)

The zoarium is uniserial, not reticulate but often forming a dividing thread by the lateral branching of the zocecial series. The zooecia are recumbent, elongate elliptical with truncated distal margin. The proximal end of the zooecium, reaching the median connecting process, of the preceding zooecium is stout and short. The opesia occupy the entire front of the zooecia. No spines are seen on the opesial margin. The operculum is of the usual type without basal sclerite. The avicularia are small, paired, situating at the distal

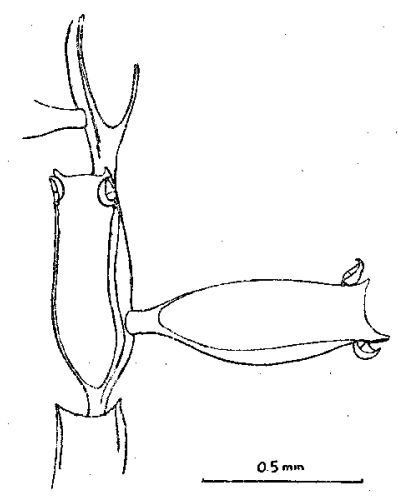

Fig. 12. Beania intermedia var kiiensis n. var.

corners of the zooecium, each carrying a small triangular mandible. The lateral connecting process is not paired, only one on each side at the level a little distally of the proximal end of the opesium. The ovicells not observed.

The present species is close to Eania intermedia, but differs from it in the smaller avicularia without peduncle, the truncate distal border, and smaller number of the lateral connecting processes.

\section{Buguia sp. (undetermined)}

Bugula neritiza var. minima OKADA and MAWATARI, 1938, p. 451.

HAstings stated (1939 p. 336) that "Specimens have also been recorded under this varietal name (B. neritina var minima WATERS) by OsBURN, and by OKADA and MAWATARI, but these identifications need confirmation now that the name is more strictly defined". 
After re-examination, my specimen was found not belonging to Bugula minima thus strictly defined.

Zooecia very small, about half length of those of normal $B$. neritina, and provided with globular avicularia quite different from that of $B$. minima. The proper position of the specimen may be defined when more complete materials obtained.

\section{Chorizopora brangniartii (AUdouIN)}

(P1. XII, Fig. 7)

Fi $u_{\text {at }}$ ra brongniartii AUDOUIN, 1826, p. 240

Lepralia brongniartii BUSK, 1854, p. 65.

Chorizopora brongniarti H NCKS, 1889, p. 224; THORNEIY, 1907, p. 188; C ANU and BASSLER, 1925 , p. $23 ; 1928$, p. $29 ; 1930$, p. 14; SAKAKURA, 1935, p. 18.

Chorizopora ventricosa CANU and BASSLER, 1929, p. 249.

The zoarium encrusts shells or barnacles, usually forming a thin silvery or grayish crust. The zooecia are delicate, pyriform or ovate separated by reticulated spaces. The frontal is an olocyst, smooth or faintly ringed transversely. Zooecial aperture is semicircular with thin peristome. A small mucro is often observed just below the orifice. The zocecium is hyperstomial, hoodlike, smooth or with a median keel, usually provided with a small avicularium on its distal summit. The avicularia are not frontal but vicarious, usually one situating just distally to the normal zooecium.

The most striking feature of this species can be seen in the structure of the peculiar interzooecial networks. In many cases the zooecia seem to be bordered by a single line of small spaces between short connecting tubes, very similar to the structure observed in Hippothoa hyalina. Sometimes a rather wide interspace separates the zooecia, filled in by a tubular network and a number of small rounded cells frequently bearing avicularian mandibles. The small cells may be recognized as vestigial zooecia, a peculiar instance of polymorphism in the Bryozoa.

CANU and BASSLER proposed another name ventricosa on their Philippine materials, and described "This new species differs from $C h$. brongniartii in its much wider zooecia with a quite different aspect". Short and wider zooecia are usually seen in many other species encrusting narrow substratum, as its main features correspond to an old species of Audouin, Ch. ventricosa may naturally be recognized as a synonym of the present species. 


\section{Schizoporella kiiensis OKADA and MAWATARI}

(Fig. 13)

Schizopodrella kizensis OKADA and MAWATARI, 1938, p. 456.

A small colony with ancestrula is newiy obtained. The ancestrula is provided with flat deformed spines extending over the opesium and meeting

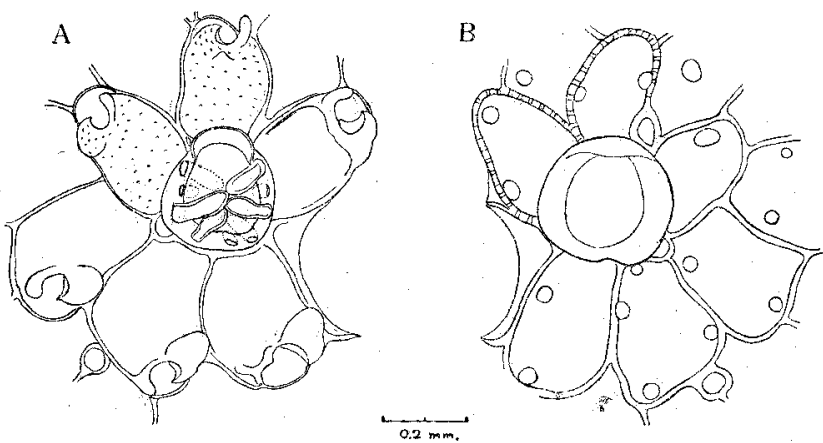

Fig. 13. Schizoporella kiiensis Okada and Mawatari

A Peculiar ancestrula and periancestrular zooecia

B Same dorsal vew

at the middle, that reminding me the formation of frontal shield of Cribrilinidae by the fusion of costae. Two or three lucidae for attachment are seen on the dorsal side of a zooecium.

\section{Fenestrulina malusï (AUDOUIN)}

(Fig. 14)

Numerous colonies with ancestrulae are observed. The ancestrula is usually of Membranipora type provided with a broad, circular opesium surroun ded by ten marginal spines. A single ancestrula is observed in having a normal frontal wall with ascopore, a normal aperture closed by an operculum, and a series of marginal spines of usual type. This may probably be due to the unusual survival of the ancestrular polypicle, and not to the total regeneration of zooecium. 


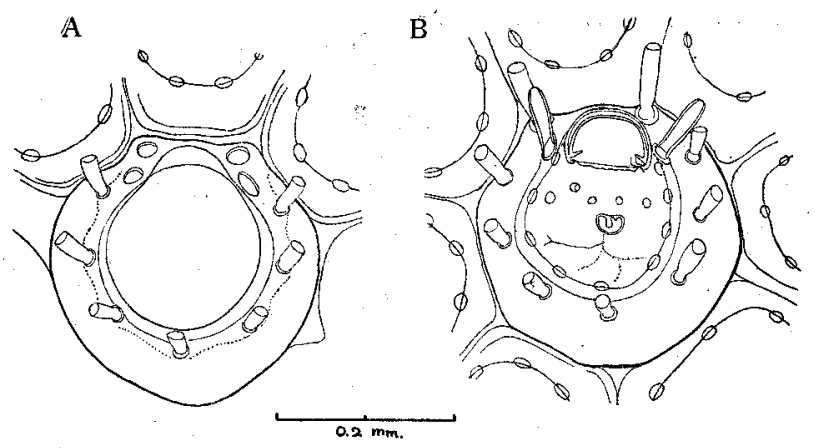

Fig. 14. Fenestrulina maiusii (Audouin)

A Usual type of ancestrula

B. Ancestrula with orifice and ascopore.

\section{Eurystomella bilabiata (HINCKs)}

Lepralia bilabiata HINCKS, 1884; p. 49; ROBERTSON, 1908, p. 298, OKADA, 1929, p. 24.

Eurystomella bilabiata LEVINSEN, 1909, p. 314; CANU and BASSLER, 1923, p. 142; SAKAKURA, 1935, p. 25.

The material at hand differs from that of Mutsu Bay in the absence of a conspicuous tubercle situated just below the aperture. Eurystomellidae was based on a single genus Eurystomella, in which included only two.species $E$. (Lapralia) foraminigera (HINks) and E. (Lepralia) bilabiata (HINCKs). Levinsen, who established the family and the genus, selected the former as a genotype, and was not certain to include the latter in the same genus. He mentioned that "There may possibly be reason however to form a special genus for the latter". I feel the same hesitation to put the present species in this genus, but the new name may be proposed when some allied species come into our knowledge.

\section{Codonella obiusata (ORTMANN)}

Lepralia obtusata ORTMANN, 1890, p. 41; OKADA and MAWATARI 1938, p. 457.

\section{Smittina aviculata sp. nov.}

(Fig. 15)

Zoarium encrusting or Escharine, uni- or bilameller. Zooecia quadrangular 
or hexagonal, rather short, distinct, separated by a salient thread. Frontal is a granular tremocyst provided wilh marginal areolar pores. Orifice circular with a distinct proximal denticle and a pair of small lateral condyles. Peristome thin, raised laterally into a collar, but usually not raised] on the distal end

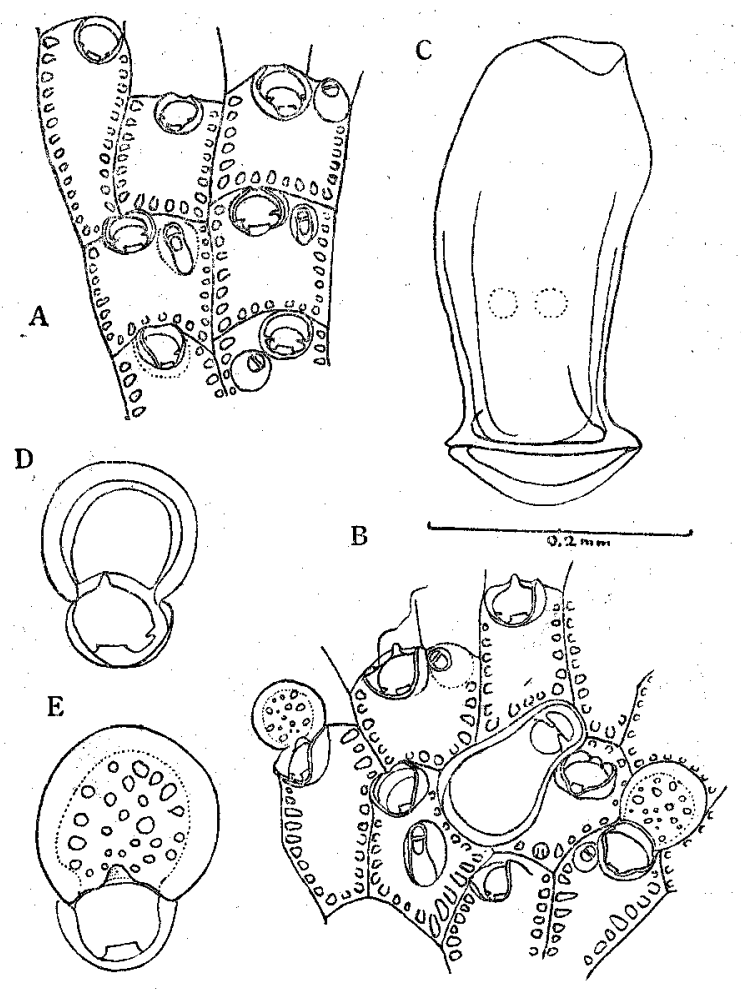

Fig. 15. Smittina aviculata n. sp.

A Normal zooecia with small semicircular and spatulate avicularia. B Enormous avicularia. C Mandible of the enormous avicularia. D. E Two stages of the development of ooecia.

of the orifice. Avicularia occur in three forms. A small rounded avicularium with semicircular mandible situates on the lateral side of the peristome. An elongated, medium-sized avicularium with spatulated mandible occur proximally or laterally to the orifice. An enormous spatulate avicularium is seen here and there in the colony, the size of which reaches almost as large as a normal zooecium. Ooecia globose with perforated frontal area. 


\section{Smittina triangulasis sp. nov.}

(Fig. 16)

Zoarium encrustiug. Zooecia distinct, rhomboidal or pentagonal, separated by a thread. Frontal is a granular tremocyst provided with marginal areolae. Orifice circular or of rounded triangle, with a narrow median denticle and two lateral condyles. Peristome salient, rather thin, with a proximal sinus. Avicularia are of four types. The elongated avicularia with peculiar elongated mandible situate one or two on a zooecium, laterally to the orifice directing obliquely backwards. Small avicularia with elongated triangular mandible scattered two or three in the neighbourhood of the orifice or in the proximal part of the zooecium.

A

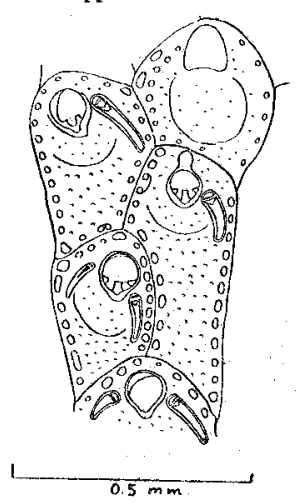

C
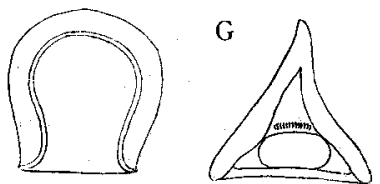

$\mathrm{H}$

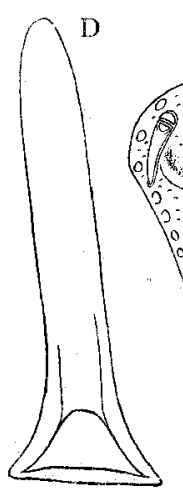

B

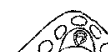

10
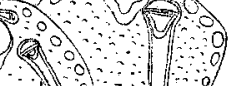

F
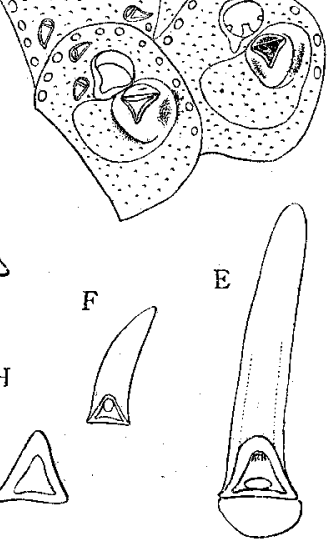

Fig. 16. Smittina triangularis n. sp.

A Zooecia with elongate avicularia. B.C Operculum D.E Large elongate avicularia $F$ Small elongate mandible $\mathrm{G}$ Large triangular mandible.

A small triangular avicularia sometimes occurs near the oriflce Large mucronated pointed ovicularium is observed in many of the zooecia situating latero-proximally to the orifice. The triangular pointed mandible strongly chitinized and yellowish in colour. Operculum semi-ellipticall with straight proximal border and submarginal sclerite. 
The present species is easily distinguished in having large elongated avicularia and strong triangular avicularia.

\section{Escharoides sauroglossa LEVINSEN 1909}

(Fig. 17)

Escharoides sauroglossa LEVINSEN, 1909, p. 319.

Smittina foliaceana OKADA and MAWATART, 1938, p. 458.

In 1890 Ortmann described Smitia adeonelloides from the Sagami Bay 60-200 fms., and OKADA found it from the Strait of Corea. In 1909 LEvinseN described Escharoides sauloglossa from $33^{\circ} 7^{\prime} \mathrm{N}$., $129^{\circ} 20^{\prime} \mathrm{E}$. and $33^{\circ} 8^{\prime} \mathrm{N}$., $129^{\circ} 20^{\prime} \mathrm{E}$.
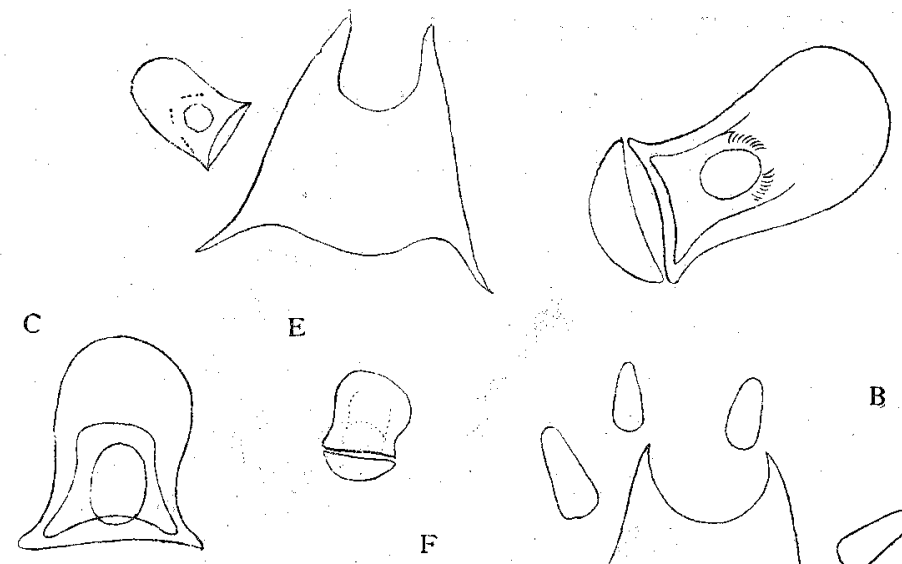

E

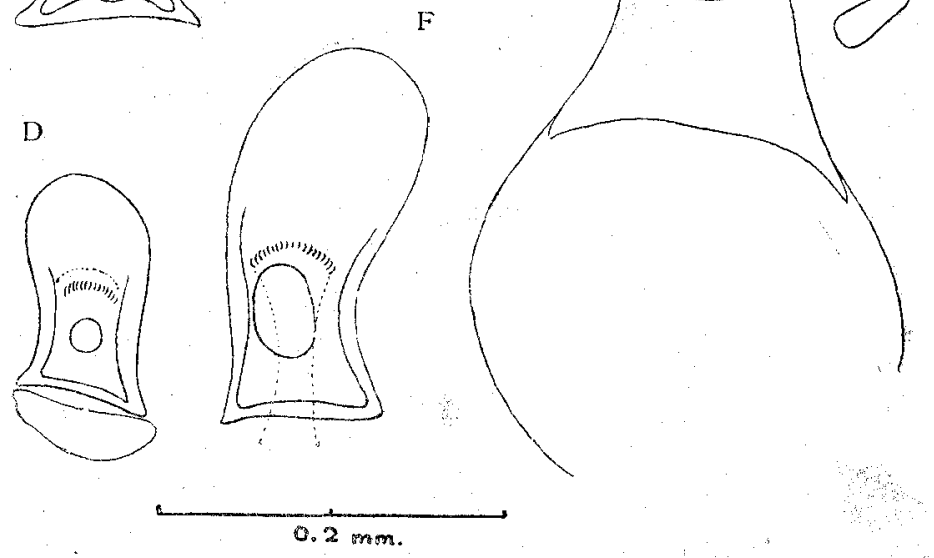

Fig. 17. Fiselaroides sauroglossa Levinsen

A Normal position of operculum and mandibles.

B Four spine-bases, Operculum and compensatrix

C-F Spatulate mandibles 
36- 40 fms., stations just corresponding to that of OKADA's specimens. SAKAKURA believed that the two species are identical with each other.

Smittina adeonelloides is reported as an erect Adeonella-type branching colony, and Escharoides sauroglossa is described as encrusting unilamellar colony.

I have found the encrusting from occur very commonly in the littoral collection of the various parts of our country, never rising up to from erect colony. The identification to the Levinsen's species is quite certain in the structure of the operculum and avicularian mandibles. The operculum and mandibles of Smittina adconelloides were not figured, but mandibles is said to be pointed, in contrast to the spatulate type of Escharoides sauroglossa.

I am now inclined to believe the two species are not identical, and may be allied ones belonging to the same genus Escharoides.

\section{Tubucellaria cereoides ELLIS and SOLANDER}

(Fig. 18; Pl. XII, Fig. 2)

Tubueellaria cereoides WATERS, 1907, p. 129; OSBURN, 1914, p. 203; CANU, 1917, p. 357 ; CANU and BASSLER, 1928, p. 113.

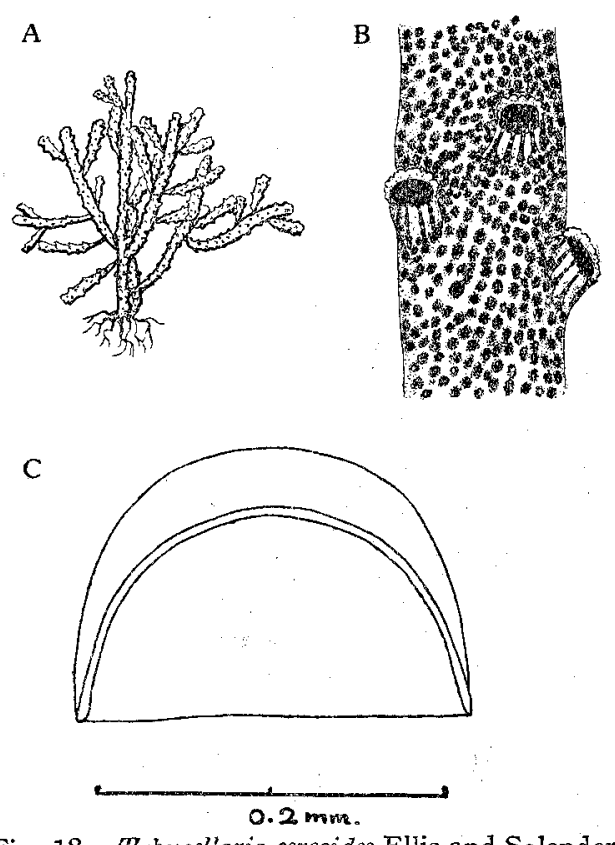

Fig. 18. Tubucellaria cereoides Ellis and Solander

A Articulated zoarium B Zooecia C Operculum

Tubular peristome distinctly curved upwards. Operculum semicircular with submarginal sclerite. 


\title{
Adeona japonica (ORTMANN)
}

\author{
(Pl. XII, Fig. 1)
}

Adeonella japonica ORT MANN, 1890, p. 54; OKADA, 1920, p. 628

Adeona japonica CANU and BAssLer, 1927, p. 34.

\section{Adeonellopsis hexangularis (OKADA)}

Adeonella hexangularis OKADA, 1920, p. 34.

\section{Watersipora cucullaia var. watersi MAWATARI}

Tepralia cucullata BUSK, 1854, p. 81; WATERS 1879, p. 40; 1909 , p. 150.

Schizoporella aterrimaORTMANN, 1890 , p. 49;

Sehizoporella oenochros (nec. ORTMANN, 1890) OKADA, 1927, p. 1528; 1934, p. 12.

Dakaria typica OKADA and MAWATARI, 1937, p. 438; 1938, p. 455."

Watersipora osnochros OKADA, 1947, p. 1386.

Watersipora cucullata HASTINGS, 1930, p. 729; MARCUS, 1937, p. 118; 1938, p. 46, 110; OSBURN, 1940 , p. $449 ; 1947$, p. 40 ; MAWATARI, 1952 , p. 14.

There has been much confusion in the systematic position of this common Bryozoa. Discussions are seen in my recent paper in 1952.

\section{Halysisis ijimai (OKADA)}

Brettia ijimai OKADA, 1921, p. 25; OKADA and MAWATARI, 1935, p. 129.

Halysisis ijimai S LEN, 1941, p. 14.

Several fragments are seen in the present collection. The species has long been known under the name of Brettia ijimai OKADA.

\section{Myriozoum superficiale ORTMANN}

İyriozoum supsrficiale ORTMANN, 1890, p. 53; OKADA, 1923, p. 231; CANU and BAsSLER, 1927 , p. 39 . 


\section{Myriozoum serratim sp. nov.}

(Fig. 19; Pl. XII, Fig. 8)

Zoarium erect, $2 \mathrm{~cm}$. in height, branching irregularly in all directions. Branches cylindrical, stout, with zooecia disposed quincuncially on all sides. Zooecia distinct, rhomboidal, separated by faintly wavy septal ridges. Frontal thick, flat, punctate. Orifice circular, with a proximal sinus. Peristome not much developed. Oral avicularium, small, a little elevated, situating just on

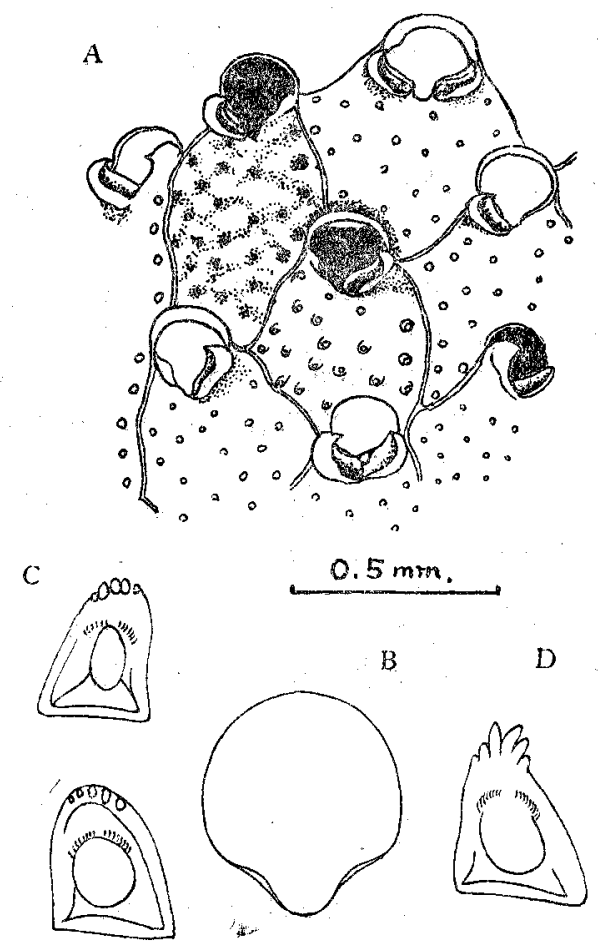

Fig. 19. Myriozoum s:rratum n. sp.

A Zooecia B Operculum

C. D Serrated mandibles

the peristome. Mandible small, triangular with minutely serrated distal margin.

This species is closely related to Myriozoum gulchrum ORTMANn especially in its position of avicularia, but differs in the peculiar serrated mandibles. WATERs treated $M$. pulchrum as a synonym of $M$. subgracile D'Oribigny, but I feel much hesitation to accept his determination. 


\section{LITERATURE CITED}

BUSK 1852, 1854. Catalogue of Marine Polyzoa. pt. 1, 2.

10 , pt. 30 .

1884. Report on the Po'yzoa collected by H.M.S. Challenger. Rep. Voy. Chall, vol.

CANU and BASSIER 1927. Bryozoaires des rles Hawaii. Bull. Soc. sci. Seine-et. Oise, fasc. 7. 1929. Bryozoa of the Philippine Region. U.S. Nat. Mus. Bull. 100, vol. 9.

HARMER 1926. The Polyzoa of the Siboga-Expedition. pt. 2. Siboga Exped. $28 \mathrm{~b}$.

HAstings 1930. Cheilostomatous Polyzoa from the vicinity of the Panama Canal. Proc. Zool. Soc. London. 1927, pt. 4.

HiNCKS 1880. A History of the British Marine Polyzoa.

LEVINSEN 1909. Morphological and systematic studies on the Cheilostomatous Bryozoa.

MARCuS 1937-1939. Bryozoarios marinhos brasileiros, 1-3, Bol. Fac. Phil. Sc. Letr. Univ. S. Paulo. Zool. nos. 1, 2, 3.

1949. Some Bryozoa from the Brazilian Coast. Com. Zool. Mus. Hist. Nat. Montevideo. vol. 3, n. 53 .

1950. Systematic Remarks on the Bryozoan fauna of Denmark. Vid. Medd. Dansk. nat. Foren. Bd. 112.

MAWATARI 1952. On Watersipora eucullata (BUSK) 1. Misc. Rep Research Inst. Natur. Res., no. 25 , p. $14_{* *} 17$.

OKADA and MA.WATARI 1938. On the collection of Bryozoa along the coast of Wakayamaken. Ann. Zool. Jap, vol. 17, Nos. 3, 4.

OSBURN 1949. The genus Parellisina. Allan Hancock Foundation Publ. Occ. pap. no. 10. 1950 Bryozoa of the Paciflc coast of America. Pt. 1. Cheilostomata-Anasca. Allan Hancock Paciflc Expeditions vol. 14, no. 1.

SAKAKURA 1935. Pliocene and pleistocene Bryozoa from the Bôso Peninsula. Journ. Fac. Sci. Imp. Univ. Tokyo, sect. 2, vol. 4. pt. 1.

S LEN 1941. Cheilostomata Anasca (Bryozoa) collected by Prof. Dr. Sixten Bock's Expedition to Japan and the Bonin Islands 1914. Ark. f. Zool., Bd. 33A, no. 12. 


\section{EXPLANATION OF PLATE XII}

Fig. 1. Adeona japonica (ORTMANN).

Fig. 2. Tubucellaria cereoides Ellis and SOLANDER.

Fig. 3. Petralia japonica (BUSK).

Fig. 4. Schizoporella unicornis (JOHNSTONE).

Fig. 5. Smittina reticulata (MACGILLIVRAY).

Fig. 6. Cellaria punctata (BUsK).

Fig. 7. Chorizopora brongniartii (Aupouin).

Fig. 8. Myriozoum serratum n. sp.

Fig. 9. Conopeum reticulum (LinNaeus).

Fig. 10. Arthropoma cecilii (Audouns).

Fig. 11. Schizoporella nivea Busk.

Fig. 12. Microporella ciliata (PALlas). 
Publ. Seto Mar. Biol. Lab., II, 2 (1952)

PLATE XII
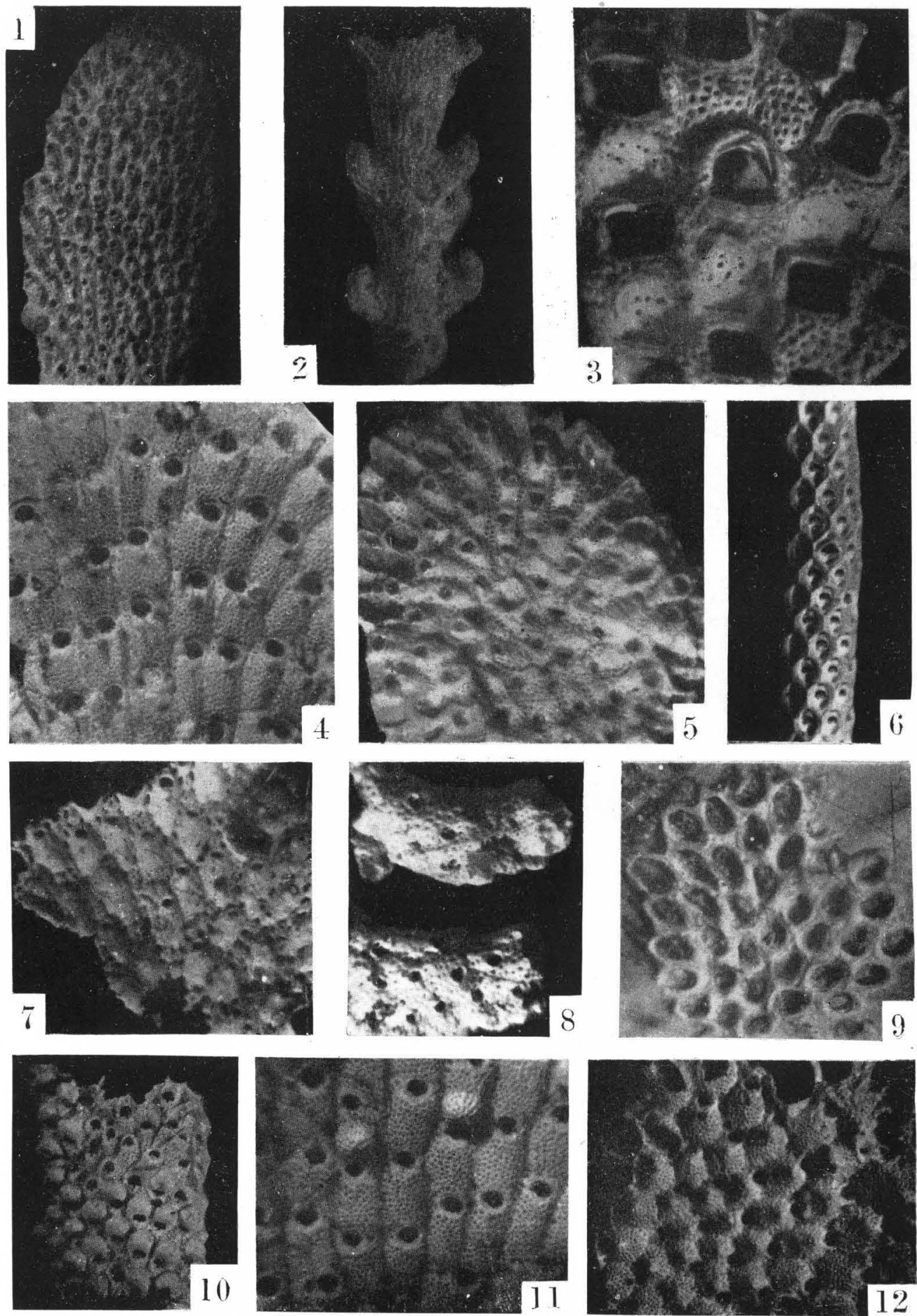

S. Mawatari: Bryozoa of Kil Peninsula. 